\title{
Selective copper diffusion into quartz-hosted vapor inclusions Evidence from other host minerals, driving forces, and consequences for $\mathrm{Cu}$-Au ore formation
}

\author{
Journal Article \\ Author(s): \\ Seo, Jung Hun; Heinrich, Christoph A. (D) \\ Publication date: \\ 2013-07-15 \\ Permanent link: \\ https://doi.org/10.3929/ethz-b-000067038
}

Rights / license:

Creative Commons Attribution-NonCommercial-NoDerivatives 4.0 International

Originally published in:

Geochimica et Cosmochimica Acta 113, https://doi.org/10.1016/j.gca.2013.03.016 
Selective copper diffusion into quartz-hosted vapor inclusions: evidence from other host minerals, driving forces, and consequences for $\mathrm{Cu}$-Au ore formation

This is the Green Open Access version of: Seo, J. H. and Heinrich, C. A., 2013. Selective copper diffusion into quartz-hosted vapor inclusions: evidence from other host minerals, driving forces, and consequences for $\mathrm{Cu}-\mathrm{Au}$ ore formation. Geochimica et Cosmochimica Acta, vol. 113, pp. 60-69. Original publication see: https://doi.org/10.1016/j.gca.2013.03.016

\title{
Selective copper diffusion into quartz-hosted vapor inclusions: evidence from other host minerals, driving forces, and consequences for $\mathrm{Cu}$-Au ore formation
}

\author{
Jung Hun Seo ${ }^{1,2, *}$ and Christoph A. Heinrich ${ }^{1,3}$ \\ ${ }_{1}^{1}$ Department of Earth Sciences, ETH Zurich, 8092 Zurich, Switzerland \\ 2 Department of Energy \& Resources Engineering, Inha University, 402-751 Incheon, Korea \\ ${ }^{3}$ also at Faculty of Mathematics and Natural Sciences, University of Zurich, Switzerland \\ *Corresponding author \\ Jung Hun SEO (seo@inha.ac.kr), Christoph A. HEINRICH (heinrich@erdw.ethz.ch)
}

Keywords: Fluid inclusion, Quartz, Topaz, Garnet, Copper diffusion, Gold, Porphyry deposit

\begin{abstract}
Recent experimental studies have raised concerns that $\mathrm{Cu}$ concentrations in quartz-hosted fluid inclusions from magmatic-hydrothermal ore deposits do not represent pristine concentrations in the trapped fluids, but are modified by post-entrapment diffusional exchange through the host quartz. New microanalyses of fluid inclusions hosted in topaz and garnet show significantly lower $\mathrm{Cu}$ concentrations in vapor inclusions, compared to otherwise identical inclusions hosted by coexisting quartz, whereas coeval brine (hypersaline liquid) inclusions are very similar independent of host mineral in one sample. Sulfur is present as a major component in all vapor inclusions, as in most porphyry-related vapor inclusions, and $\mathrm{Cu}$ never exceeds $\mathrm{S}$, but commonly matches the $\mathrm{S}$ content at a molar ratio of $\mathrm{Cu}: \mathrm{S} \leq 2$ in vapor inclusions hosted by quartz.

Univalent ions with a radius smaller than $\sim 1 \AA$ are known to diffuse rapidly through the channels of the quartz structure, parallel to its crystallographic c axis. Since only $\mathrm{Cu}$ concentrations differ between topaz- and quartz-hosted inclusions, we hypothesize that $\mathrm{Cu}^{+}$and $\mathrm{H}^{+}$re-equilibrate by diffusional ion exchange through these channels, while all other element concentrations remain
\end{abstract}


Selective copper diffusion into quartz-hosted vapor inclusions: evidence from other host minerals, driving forces, and consequences for $\mathrm{Cu}$-Au ore formation

essentially unchanged. A thermodynamic model considering charge-balanced $\mathrm{Cu}^{+}-\mathrm{H}^{+}$exchange and diffusive $\mathrm{H}_{2}$ re-equilibration of an initially $\mathrm{Cu}$-poor but $\mathrm{S}$-rich vapor inclusion with a typical rockbuffered fluid environment outside the host crystal demonstrates a strong chemical driving force for $\mathrm{Cu}^{+}$to migrate from the surrounding rock into the fluid inclusion during cooling of the system. The driving force for $\mathrm{Cu}$ diffusion, against the gradient in total $\mathrm{Cu}$ concentration, is the abundant $\mathrm{H}^{+}$ liberated inside the inclusion by dissociation of $\mathrm{HCl}$ and particularly by the precipitation of $\mathrm{CuFeS}_{2}$ by reaction with the initially trapped $\mathrm{H}_{2} \mathrm{~S}$ and/or $\mathrm{SO}_{2}$. Gold is not only a much larger ion, but is subject to an opposing driving force, suggesting that high concentrations of this larger ion analyzed in vapor inclusions probably represent true gold concentrations in magmatic-hydrothermal vapor.

These findings imply that brine - vapor separation in porphyry deposits does not cause selective $\mathrm{Cu}$ transfer to the vapor, but is more likely to destabilize $\mathrm{Cu}$ complexes and promote copper ore deposition during decompression and unmixing of the two fluid phases. By contrast, Au may be selectively transferred into the vapor phase, allowing its transport through the deeper porphyry copper deposits to form epithermal gold deposits closer to the earth's surface.

\section{Introduction}

Quartz has been the favored host mineral for fluid inclusion studies of magmatic and other hydrothermal ore deposits, because of its common association with ore minerals, its transparency and its chemically simple composition. Quartz veins and euhedral quartz crystals from hightemperature magmatic-hydrothermal deposits and miarolitic cavities in granitoids contain large fluid inclusions in diverse assemblages, which preserve distinct and internally consistent compositions and densities among numerous individual coeval inclusions. Magmatic-hydrothermal fluid inclusions in petrographically controlled context therefore provide abundant information about high-temperature processes including pressure-temperature evolution, phase state of fluids, metal transportation and precipitation, and the segregation of elements during phase separation into fluids of different densities (Cloke and Kesler, 1979; Eadington, 1983; Roedder, 1984; Cline and Bodnar, 1991; Bodnar and Vityk, 1994; Audétat et al., 1998). Fluid densities as well as salinity are important factors for the mobility of metals as well as volatiles in magmatic-hydrothermal environments. Selective metal transportation in immiscible two-phase fluids, a high-density hypersaline aqueous liquid (brine) coexisting with a vapor phase of lower density and salinity, has been of particular interest in ore deposit research and related experimental studies (Krauskopf, 1964; Henley and McNabb, 1978; Eastoe, 1982; Heinrich et al., 1992; Pokrovski et al., 2005; Williams-Jones and Heinrich, 2005; Simon et al., 2006; Pokrovski et al., 2008; Seo et al., 2009; Frank et al., 2011).

Copper has long been known to be highly concentrated in low-density vapor inclusions hosted in quartz from magmatic-hydrothermal systems. Vapor inclusions in magmatic-hydrothermal quartz veins (i.e., inclusions that trapped the vapor as a homogeneous fluid sample at high temperatures and pressures) commonly contain chalcopyrite daughter crystals after cooling that are similar or even larger in size than those in coexisting brine inclusions. High $\mathrm{Cu}$ concentrations in the vapor inclusions were initially estimated based on the size of the chalcopyrite daughter crystals (Sawkins 
Selective copper diffusion into quartz-hosted vapor inclusions: evidence from other host minerals, driving forces, and consequences for $\mathrm{Cu}$-Au ore formation

and Scherkenbach, 1981; Roedder, 1984). Micro-PIXE (Proton Induced X-ray Emission) and LA-ICPMS (Laser Ablation Inductively Coupled Plasma Mass Spectrometry) analyses of individual inclusions in distinct assemblages allowed quantification of the selective enrichment of $\mathrm{Cu}$, As, and $\mathrm{Au}$ in low-density vapor inclusion, whereas major salt components and trace elements such as $\mathrm{Na}, \mathrm{K}$, $\mathrm{Fe}, \mathrm{Mn}, \mathrm{Zn}, \mathrm{Rb}, \mathrm{Cs}$, and $\mathrm{Pb}$ were shown to be enriched in coexisting brine inclusions (Heinrich et al., 1992; Ryan et al., 1993; Damman et al., 1996; Heinrich et al., 1999; Ulrich et al., 1999; Baker et al., 2004). This chemical separation was interpreted to result from volatile sulfur complexing of $\mathrm{Cu}$ and $\mathrm{Au}$ at magmatic-hydrothermal fluid conditions, consistent with recent observations that the $\mathrm{Cu}$-rich vapor inclusions also contain an equivalent or even larger enrichment of S (Seo et al., 2009). Hydrothermal experiments with S-bearing two-phase fluids confirmed relatively elevated $\mathrm{Cu}$ concentrations in the vapor phase, compared to the vapor in S-free fluid systems (Simon et al., 2006; Nagaseki and Hayashi, 2008; Pokrovski et al., 2008; Frank et al., 2011), but only the study of Nagaseki and Hayashi (2008) using synthetic fluid inclusion in quartz reported higher absolute concentrations of $\mathrm{Cu}$ in vapor compared to coexisting brine.

Recent experiments have shown that $\mathrm{Cu}$ concentration in melt and fluid inclusions can be modified after their entrapment in quartz. Zajacz et al. (2009) and Li et al. (2009) demonstrated significant compositional modification of fluid and melt inclusions hosted in quartz, by selective diffusional exchange with surrounding hydrothermal fluids of $\mathrm{Li}^{+}, \mathrm{Na}^{+}, \mathrm{Cu}^{+}$and $\mathrm{Ag}^{+}$through the host mineral. Such quantitative experiments in cold-seal bombs quantified earlier suspicions reported by Kamenetsky and Danyushevsky (2005). Lerchbauer and Audétat (2012) recently performed systematic re-equilibration experiments using brine and vapor inclusions coexisting in individual quartz samples, which were loaded into a pressure vessel with an external fluid of variable composition. The authors showed that the initial S content of quartz-hosted fluid inclusion can promote inward diffusion of $\mathrm{Cu}$ from the external hydrothermal fluid, by precipitation of a $\mathrm{Cu}$ sulfide crystal inside the inclusion. The proposed inward diffusion provides $\mathrm{Cu}$ until the activities of $\mathrm{Cu}^{+}, \mathrm{H}^{+}$, and $\mathrm{H}_{2} \mathrm{~S}$ in the inclusion reach a chemical equilibrium with the external fluid (Lerchbaumer and Audétat, 2012), which allows the internal precipitation of $\mathrm{CuFeS}_{2}$ consistent with the observed positive correlation of 1:2 molar ratios of $\mathrm{Cu}$ and $\mathrm{S}$ in many natural quartz-hosted inclusion assemblages from magmatic-hydrothermal ore deposits (Seo et al., 2009).

Here, we complement these experimental data with new results of LA-ICP-MS microanalysis of natural topaz- and garnet-hosted fluid inclusions. We chose topaz and garnet, because they are mechanically strong and have generally lower chemical diffusivity compared to quartz (Brady and Cherniak, 2010). Due to their different crystal structures, these minerals are expected to be less, or at least differently, affected by post-entrapment diffusional exchange (Ingrin and Blanchard, 2006) and therefore provide an independent test for the proposed, element-specific behavior of quartz as an inclusion host.

\section{Samples and Analytical Methods}

The topaz samples are from wolframite-bearing quartz - topaz greisen of the Fielders Hill deposit located in a roof pendent of the Mole Granite, Australia (Eadington, 1983; Audétat et al., 2000). The 
Selective copper diffusion into quartz-hosted vapor inclusions: evidence from other host minerals, driving forces, and consequences for $\mathrm{Cu}$-Au ore formation

garnet sample is from the Dongguashan skarn $\mathrm{Cu}$ deposit, which is spatially related to a subeconomic porphyry deposit in the Tongling district, China (Yang et al., 2009). Cogenetic assemblages of single trails (healed microcracks) comprising coeval brine and vapor inclusions (traditionally termed 'boiling assemblages') were analyzed in topaz. Consistently large bubble/liquid proportions in the vapor inclusions and constant bubble/liquid/halite proportions in the brine inclusions at room temperature indicate that each inclusion type approximates a homogeneous fluid phase. The two fluids coexisted at elevated pressures and temperatures and were isolated from each other by rapid healing of microcracks in the host minerals. A boiling assemblage hosted in quartz in the same sample was also analyzed for comparison, in addition to quartz data from the same location reported previously by Audétat et al. (2000) and Seo et al. (2009). We were not successful in finding individual inclusion trails crossing a grain boundary between quartz and topaz. Nevertheless, the close intergrowth of both minerals in sample Fiel_32b and the similarity of fluid inclusion associations in samples from the same and other localities in the Mole Granite indicate that we are comparing coeval brine and vapor inclusions in the two host minerals. The garnet from the Dongguashan skarn contains vapor inclusions only, which cannot be reliably correlated with quartz-hosted inclusions in the spatially associated porphyry-style mineralization in the same deposit (Yang et al., 2009).

Representative fluid inclusion assemblages (FIA) comprising 5-12 individual inclusions of each type, hosted in topaz, garnet and quartz, were selected by detailed petrography. Microthermometry was conducted to determine halite dissolution and homogenization temperatures of brine inclusions. Obtaining ice melting temperatures to determine salinities of most vapor inclusions was difficult because of the thin layer of aqueous liquid around the walls of inclusions, which were generally much smaller $(\sim<25 \mu \mathrm{m})$ than those hosted in quartz from the Mole Granite. Brine inclusions in quartz and topaz have essentially identical properties, but in light of the incomplete microthermometric data for most vapor inclusions we report our data in terms of element ratios. These are determined directly by LA-ICP-MS and can be calibrated quantitatively, without any assumptions (Günther et al., 1998). We normalized elements concentrations with $\mathrm{Pb}$ rather than $\mathrm{Na}$ because $\mathrm{Pb}$ can be measured more precisely by LA-ICP-MS due to its greater abundance sensitivity, and $\mathrm{Pb}$ is exclusively chloride complexed in high-temperature hydrothermal fluids (Seward, 1984). $\mathrm{Na}$ concentrations in quartz-hosted fluid inclusions may also be subject to modifications by postentrapment diffusion (Li et al., 2009; Zajacz et al., 2009; Lerchbaumer and Audétat, 2012).

We measured singly-targeted fluid inclusions in representative fluid inclusion assemblages using the ETH-prototype LA-ICP-MS system (Günther et al., 1998). A limited number of isotopes, ${ }^{7} \mathrm{Li},{ }^{23} \mathrm{Na}$, ${ }^{32} \mathrm{~S},{ }^{35} \mathrm{Cl},{ }^{39} \mathrm{~K},{ }^{57} \mathrm{Fe},{ }^{65} \mathrm{Cu},{ }^{66} \mathrm{Zn},{ }^{75} \mathrm{As},{ }^{95} \mathrm{Mo},{ }^{107} \mathrm{Ag},{ }^{133} \mathrm{Cs},{ }^{197} \mathrm{Au}$, and ${ }^{208} \mathrm{~Pb}$ were measured, applying an increased dwell time on selected elements (50-100 ms for ${ }^{197} \mathrm{Au}, 20 \mathrm{~ms}$ for ${ }^{95} \mathrm{Mo}, 20 \mathrm{~ms}$ for ${ }^{32} \mathrm{~S}$ and ${ }_{35} \mathrm{Cl}$, and $10 \mathrm{~ms}$ for other elements). A small flux of $\mathrm{H}_{2}$ gas ( $5 \mathrm{ml} / \mathrm{min}$ ) was added to the He carrier gas $(1.1 \mathrm{l} / \mathrm{min})$ to enhance sensitivity for heavier elements such as $\mathrm{Cu}, \mathrm{Au}$, and $\mathrm{Mo}$ (Guillong and Heinrich, 2007). Energy densities between 30 and $40 \mathrm{~J} / \mathrm{cm}^{2}$ on the sample surface with $10 \mathrm{~Hz}$ pulse frequency allowed controlled sampling of most quartz- and garnet-hosted fluid inclusions, while higher repetition rates of $20 \mathrm{~Hz}$ pulse frequency were applied for topaz-hosted fluid inclusions 
Selective copper diffusion into quartz-hosted vapor inclusions: evidence from other host minerals, driving forces, and consequences for $\mathrm{Cu}$-Au ore formation

analysis. An iris aperture was gradually opened during analysis to a spot size allowing complete excavation of the fluid inclusion without the loss of daughter crystals. We used a natural scapolite as an external standard reference material (SRM) for ${ }^{35} \mathrm{Cl}$ (Seo et al., 2011), while NIST SRM 610 was used for all other elements. Quantification of elements followed the data reduction procedures of Günther et al. (1998) and Heinrich et al. (2003) using the SILLS software (Guillong et al., 2008). The average and $1 \sigma$ variation within each assemblage is calculated from all quantifiable inclusion signals for each element, to give an estimate of realistic analytical uncertainty of each fluid composition represented by an assemblage (Heinrich et al., 2003; Table 1).

\section{Results}

Copper concentrations in the vapor inclusions can be compared by normalizing the analysed element ratios to a previously measured salinity of $3 \mathrm{wt} \% \mathrm{NaCl}$ eqv. of many vapor inclusion assemblages in the Mole Granite (Audétat et al., 2000; Seo et al., 2009). Copper ranges from $56 \pm 18$ $\mu \mathrm{g} / \mathrm{g}$ to $160 \pm 98 \mu \mathrm{g} / \mathrm{g}$ in several topaz-hosted assemblages of vapor inclusions, and from $66 \pm 34$ $\mu \mathrm{g} / \mathrm{g}$ to $74 \pm 24 \mu \mathrm{g} / \mathrm{g}$ in the garnet-hosted vapor inclusion assemblages. These values are comparable to typical $\mathrm{Cu}$ concentrations expected experimentally predicted for a high-temperature magmatic vapor of moderate salinity, exsolving from a moderately reduced andesitic melt (Zajacz et al., 2011). Sulfur concentrations in vapor inclusion assemblages range from $\sim 1,000 \mu \mathrm{g} / \mathrm{g}$ to $9,900 \pm$ $1,900 \mu \mathrm{g} / \mathrm{g}$ in topaz-hosted and from $8,200 \pm 2,900 \mu \mathrm{g} / \mathrm{g}$ to $11,000 \pm 4,900 \mu \mathrm{g} / \mathrm{g}$ in garnet-hosted assemblages. Copper concentrations in topaz-hosted brine inclusion assemblages vary from $700 \pm$ $83 \mu \mathrm{g} / \mathrm{g}$ to $1,100 \pm 270 \mu \mathrm{g} / \mathrm{g}$, and S concentrations are from $230 \pm 14 \mu \mathrm{g} / \mathrm{g}$ to $1,100 \pm 800 \mu \mathrm{g} / \mathrm{g}$. In topaz and garnet, vapor inclusion assemblages contain $\mathrm{S}$ in excess compared to $\mathrm{Cu}$, whereas brine inclusions have similar or even higher $\mathrm{Cu}$ than $\mathrm{S}$. Such $\mathrm{Cu}$ excess compared to $\mathrm{S}$ has never been found in quartz-hosted fluid inclusions (Cauzid et al., 2007; Seo et al., 2009; Seo et al., 2011).

Gold was not detected in the transient signals of the topaz- and garnet-hosted vapor inclusions, whereas some brine inclusions hosted in topaz contain Au between $0.06 \pm 0.00 \mu \mathrm{g} / \mathrm{g}$ and $0.28 \pm$ $0.24 \mu \mathrm{g} / \mathrm{g}$, which is comparable to the gold concentrations in quartz-hosted brine inclusions (Table 1). Detection of $\mathrm{Au}$, especially in vapor inclusions hosted by topaz is hampered by the small total fluid mass and the small inclusion size, compared with the typically larger quartz-hosted inclusions. According to individually calculated limits of detection, the gold concentration in topaz-hosted vapor inclusions may be as high as in those hosted by quartz.

The cogenetic brine and vapor inclusions trapped in the single healed crack (boiling assemblage) hosted in topaz show no selective $\mathrm{Cu}$ enrichment in the vapor inclusions compared to the coexisting brine inclusions. By contrast, As and S are relatively enriched in vapor inclusions (Fig. 1), to a similar degree as shown by the quartz-hosted inclusions. Boiling assemblages hosted in coexisting quartz, by contrast, show a high degree of selective $\mathrm{Cu}$ enrichment in the vapor inclusions, which correlates with that of $\mathrm{S}$, similar to numerous other quartz-hosted vapor - brine assemblages worldwide. When the ratios of $\mathrm{Cu}$ to other ore and alkali metals are compared between topaz- and quartz-hosted boiling assemblages, up to three orders of magnitude of discrepancy is found in the Fielders Hill samples (Fig. 1). We also found minor differences for Li and Ag ratios, whereas the 
Selective copper diffusion into quartz-hosted vapor inclusions: evidence from other host minerals, driving forces, and consequences for $\mathrm{Cu}$-Au ore formation

element ratios between vapor and brine, for all other metals including $\mathrm{Na}$, are not significantly different between the host minerals. 
Selective copper diffusion into quartz-hosted vapor inclusions: evidence from other host minerals, driving forces, and consequences for

$\mathrm{Cu}-\mathrm{Au}$ ore formation

Table 1

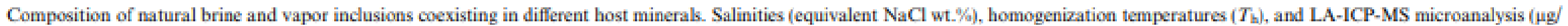
g) of eight cogenetic brine and vapor inclusions hosted in topaz and quartz, and two vapor-rich inclusion assemblages hosted in garnet. "Fiel" and "Boyd" samples are from quartz-topaz greisen, and "gold" sample is from Bi-rich quartz vein associated with Mole Granite, Australia (Audétat et al., 2000; Seo et al., 2009). "54-5" sample is from Cu-rich garnet skarn at Dongguashan porphyry-skarn Cu deposit, China (Yang et al., 2009). Salinities of some vapor-rich inclusion assemblages are assumed to be 3 wt.\% NaCl eqv. Detection limits of Au are reported when no reliable Au peak from LA-ICP-MS transient signals of fluid inclusion are found.

\begin{tabular}{|c|c|c|c|c|c|c|c|c|c|c|c|c|c|c|c|c|c|c|c|}
\hline & $\begin{array}{l}\text { Host } \\
\text { mineral }\end{array}$ & $\begin{array}{l}\text { Sample \# } \\
\text { FI \# }\end{array}$ & Phase & $\begin{array}{l}\text { Salinity } \\
\text { wt.\% } \mathrm{NaCl} \text { eqv. }\end{array}$ & $T_{\mathrm{h}}$ & $\begin{array}{l}{ }^{7} \mathrm{Li} \\
\mu \mathrm{g} / \mathrm{g}\end{array}$ & $\begin{array}{l}{ }^{23} \mathrm{Na} \\
\mu \mathrm{g} / \mathrm{g}\end{array}$ & $\begin{array}{l}{ }^{32} \mathrm{~S} \\
\mu \mathrm{g} / \mathrm{g}\end{array}$ & $\begin{array}{l}{ }^{35} \mathrm{Cl} \\
\mu \mathrm{g} / \mathrm{g}\end{array}$ & $\begin{array}{l}{ }^{39} \mathrm{~K} \\
\mu \mathrm{g} / \mathrm{g}\end{array}$ & $\begin{array}{l}{ }^{57} \mathrm{Fe} \\
\mu g / g\end{array}$ & $\begin{array}{l}{ }^{65} \mathrm{Cu} \\
\mu \mathrm{g} / \mathrm{g}\end{array}$ & $\begin{array}{l}{ }^{66} \mathrm{Zn} \\
\mu \mathrm{g} / \mathrm{g}\end{array}$ & $\begin{array}{l}{ }^{75} \mathrm{As} \\
\mu \mathrm{g} / \mathrm{g}\end{array}$ & $\begin{array}{l}{ }^{95} \mathrm{Mo} \\
\mu \mathrm{g} / \mathrm{g}\end{array}$ & $\begin{array}{l}{ }^{107} \mathrm{Ag} \\
\mu \mathrm{g} / \mathrm{g}\end{array}$ & $\begin{array}{l}{ }^{133} \mathrm{Cs} \\
\mu \mathrm{g} / \mathrm{g}\end{array}$ & $\begin{array}{l}{ }^{197} \mathrm{Au} \\
\mu \mathrm{g} / \mathrm{g}\end{array}$ & $\begin{array}{l}{ }^{2063} \mathrm{~Pb} \\
\mu \mathrm{g} / \mathrm{g}\end{array}$ \\
\hline$\overline{\mathrm{AV}}$ & Topaz & Fiel 1.11 & Vapor & 3.0 & n.d. & 440 & 6700 & 1400 & 6000 & 4100 & 5900 & 56 & 400 & 170 & 0.5 & 1.9 & 350 & $<0.63$ & 100 \\
\hline STD & & $\mathrm{TP1}^{-}$ & (boil) & Assum. & & 54 & 510 & 960 & 3000 & 680 & 1100 & 18 & 130 & 56 & 0.2 & 0.7 & 100 & & 34 \\
\hline $\mathrm{AV}$ & & & Brine & 36.0 & n.d. & 1200 & 72,000 & 230 & 100,000 & 64,000 & 88,000 & 710 & 6200 & 400 & 2.3 & 39.0 & 5400 & $<0.75$ & 1800 \\
\hline STD & & & (boil) & 0.2 & & 310 & 4600 & 14 & 18,000 & 6100 & 6000 & 160 & 1500 & 180 & 1.0 & 3.6 & 1300 & & 250 \\
\hline AV & Topaz & Fiel_1.1_1 & Vaper & 3.0 & n.d. & 380 & 7000 & 2400 & 5800 & 3100 & 6300 & 74 & 370 & 400 & 0.6 & 2.3 & 300 & $<0.54$ & 98 \\
\hline STD & & TP6 & (boil) & Assum. & & 56 & 480 & 1500 & 1900 & 790 & 620 & 13 & 160 & 260 & 0.6 & 1.5 & 88 & & 36 \\
\hline AV & & & Brine & 35.3 & n.d. & 1300 & 67,000 & 420 & 100,000 & 62,000 & 96,000 & 1100 & 4900 & 370 & 1.6 & 31.0 & 3100 & $<1.29$ & 1800 \\
\hline STD & & & (boil) & 0.2 & & 210 & 5800 & 300 & 19,000 & 8300 & 5800 & 180 & 850 & 52 & 0.4 & 3.9 & 600 & & 140 \\
\hline AV & Topaz & Fiel_1.1_1 & Vapor & 3.0 & n.d. & 400 & 7100 & 1000 & 6100 & 3800 & 5700 & 64 & 330 & 230 & 1.1 & 2.2 & 190 & $<0.11$ & 58 \\
\hline STD & & $\mathrm{TP} 2$ & (boil) & Assum. & & 85 & 680 & 1100 & 1800 & 830 & 1000 & 14 & 83 & 110 & 0.3 & 0.8 & 50 & & 10 \\
\hline AV & & & Brine & 31.3 & n.d. & 1700 & 68,000 & 260 & 90,000 & 54,000 & 67,000 & 700 & 4000 & 690 & 7.4 & 37.0 & 2300 & $<0.10$ & 680 \\
\hline STD & & & (boil) & 0.1 & & 290 & 3100 & 170 & 13,000 & 3600 & 5000 & 83 & 450 & 140 & 6.6 & 3.5 & 610 & & 130 \\
\hline AV & Topaz & Fiel_32b_1 & Vapor & 3.0 & n.d. & 2300 & 6400 & 9200 & 13,000 & 3400 & 8700 & 110 & 410 & 3000 & & 3.8 & 110 & $<0.36$ & 51 \\
\hline STD & & TP1 & (boil) & Assum. & & 390 & 500 & 3900 & 6400 & 990 & 1500 & 17 & 200 & 450 & & 3.2 & 29 & & 17 \\
\hline AV & & & Brine & 33.6 & 546.7 & 1700 & 60,000 & 1100 & 73,000 & 65,000 & 97,000 & 860 & 7500 & 820 & 3.9 & 54.0 & 6700 & 0.28 & 2100 \\
\hline STD & & & (boil) & 0.1 & 7.6 & 980 & 4000 & 800 & 16,000 & 5900 & 8900 & 270 & 2200 & 590 & 2.2 & 25.0 & 840 & 0.24 & 210 \\
\hline AV & Topaz & Fiel_32b_1 & Vapor & 3.0 & n.d. & 3200 & 6900 & 9900 & 18,000 & 3700 & 8300 & 160 & 500 & 3200 & & 4.5 & 140 & $<1.72$ & 70 \\
\hline STD & & TP2 & (boil) & Assum. & & 830 & 1300 & 1900 & & 1500 & 2500 & 98 & 230 & 1400 & & 1.9 & 58 & & 21 \\
\hline AV & & & Brine & 35.0 & 544.7 & 900 & 66,000 & 460 & 100,000 & 69,000 & 93,000 & 1100 & 5200 & 370 & 8.5 & 48.0 & 3600 & 0.06 & 1200 \\
\hline STD & & & (boil) & 1.6 & 7.5 & 160 & 4300 & 340 & 33,000 & 7800 & 5900 & 270 & 880 & 93 & 5.8 & 12.0 & 1200 & 0.00 & 550 \\
\hline AV & Topaz & Fiel_1.1_1 & Vapor & 3.0 & n.d. & 420 & 7300 & 4400 & 8300 & 3600 & 5300 & 100 & 310 & 420 & 1.5 & 1.6 & 130 & $<1.18$ & 92 \\
\hline STD & & v7 & (non-boil) & Assum. & & 170 & 870 & 2500 & 3900 & 1800 & 2700 & 53 & 140 & 170 & 0.7 & 0.8 & 49 & & 41 \\
\hline $\begin{array}{l}\text { AV } \\
\text { STD }\end{array}$ & Garnet & $\begin{array}{l}54-5 \_2 \\
\text { TP1 }\end{array}$ & $\begin{array}{l}\text { Vapor } \\
\text { (non-boil) }\end{array}$ & $\begin{array}{l}3.0 \\
\text { Assum. }\end{array}$ & n.d. & $\begin{array}{l}170 \\
140\end{array}$ & $\begin{array}{l}9700 \\
590\end{array}$ & $\begin{array}{l}11,000 \\
4900\end{array}$ & $\begin{array}{l}53,000 \\
8300\end{array}$ & $\begin{array}{l}5100 \\
1400\end{array}$ & & $\begin{array}{l}66 \\
34\end{array}$ & $\begin{array}{l}460 \\
360\end{array}$ & & & & $\begin{array}{l}16 \\
7\end{array}$ & $<1.40$ & $\begin{array}{l}100 \\
41\end{array}$ \\
\hline $\mathrm{AV}$ & Garnet & $54-5 \_2$ & Vapor & 3.0 & n.d. & 320 & 8100 & 8200 & 93,000 & 9100 & & 74 & 450 & & & 13.0 & 38 & $<3.34$ & 210 \\
\hline STD & & v2 & (non-boil) & Assum. & & 200 & 1900 & 2900 & 16,000 & 5500 & & 24 & 360 & & & 2.4 & 30 & & 120 \\
\hline AV & Quartz & Gold_1.2.2 & Vapor & 2.4 & n.d. & 450 & 7600 & 9800 & 10,000 & 2500 & 3400 & 5400 & 260 & 410 & 1.0 & 9.6 & 86 & 0.32 & 220 \\
\hline STD & & & (boil) & 0.5 & & 160 & 1000 & 8000 & 6200 & 690 & 1400 & 3600 & 130 & 370 & 0.4 & 8.8 & 34 & 0.25 & 120 \\
\hline AV & & & Brine & 37.4 & 356.0 & 480 & 85,000 & 340 & 360,000 & 77,000 & 120,000 & 290 & 8800 & 310 & 1.4 & 59.0 & 3400 & 0.04 & 8900 \\
\hline STD & & & (boil) & 0.4 & 19.0 & 110 & 16,000 & 140 & 23,000 & 17,000 & 23,000 & 130 & 2000 & 230 & 0.8 & 6.2 & 970 & 0.03 & 2600 \\
\hline AV & Quartz & BoydB_1 & Vaper & 3.3 & n.d. & 100 & 10,000 & 12,000 & 13,000 & 3300 & 4000 & 8200 & 390 & 130 & 5.8 & 26.0 & 140 & 0.38 & 180 \\
\hline STD & & & (boil) & & & 72 & 1000 & 8800 & 3000 & 1100 & 1100 & 11,000 & 190 & 140 & 6.5 & 22.0 & 28 & 0.19 & 74 \\
\hline AV & & & Brine & 39.6 & n.d. & 550 & 96,000 & 710 & 370,000 & 79,000 & 110,000 & 240 & 6500 & 260 & 4.4 & 48.0 & 3800 & 0.13 & 3900 \\
\hline STD & & & (boil) & 0.4 & & 370 & 19,000 & 370 & 44,000 & 12,000 & 12,000 & 150 & 1300 & 340 & 8.8 & 7.9 & 1400 & 0.25 & 1200 \\
\hline AV & Quartz & Fiel_32b_2 & Vapor & 3.0 & n.d. & & 9200 & 1200 & 16,000 & 3700 & 5400 & 370 & 950 & 26 & & 2.7 & 250 & $<2.28$ & 310 \\
\hline STD & & TP1 & (boil) & Assum. & & & 930 & 660 & 9400 & 1100 & 2100 & 550 & 350 & 14 & & & 76 & & 130 \\
\hline AV & & & Brine & 40.5 & 263.7 & 76 & 110,000 & 1500 & 290,000 & 58,000 & 91,000 & 120 & 15,000 & 360 & & 37.0 & 5300 & 0.35 & 4600 \\
\hline STD & & & (boil) & 1.6 & 5.5 & & 21,000 & & 62,000 & 15,000 & 19,000 & 34 & 4300 & 110 & & 19.0 & 1700 & 0.17 & 1400 \\
\hline
\end{tabular}

AV and STD represent average and standard deviation $(1 \sigma)$ of 5-12 single fluid inclusion analyses in an inclusion assemblage of petrographically identical and coeval inclusions; where $1 \sigma$ is similar

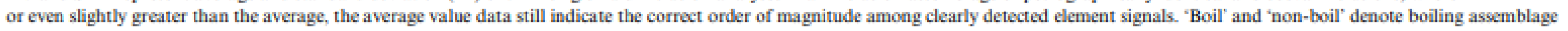
and single-phase fluid inclusion assemblage, respectively. n.d. represent no data. 
Selective copper diffusion into quartz-hosted vapor inclusions: evidence from other host minerals, driving forces, and consequences for $\mathrm{Cu}$-Au ore formation

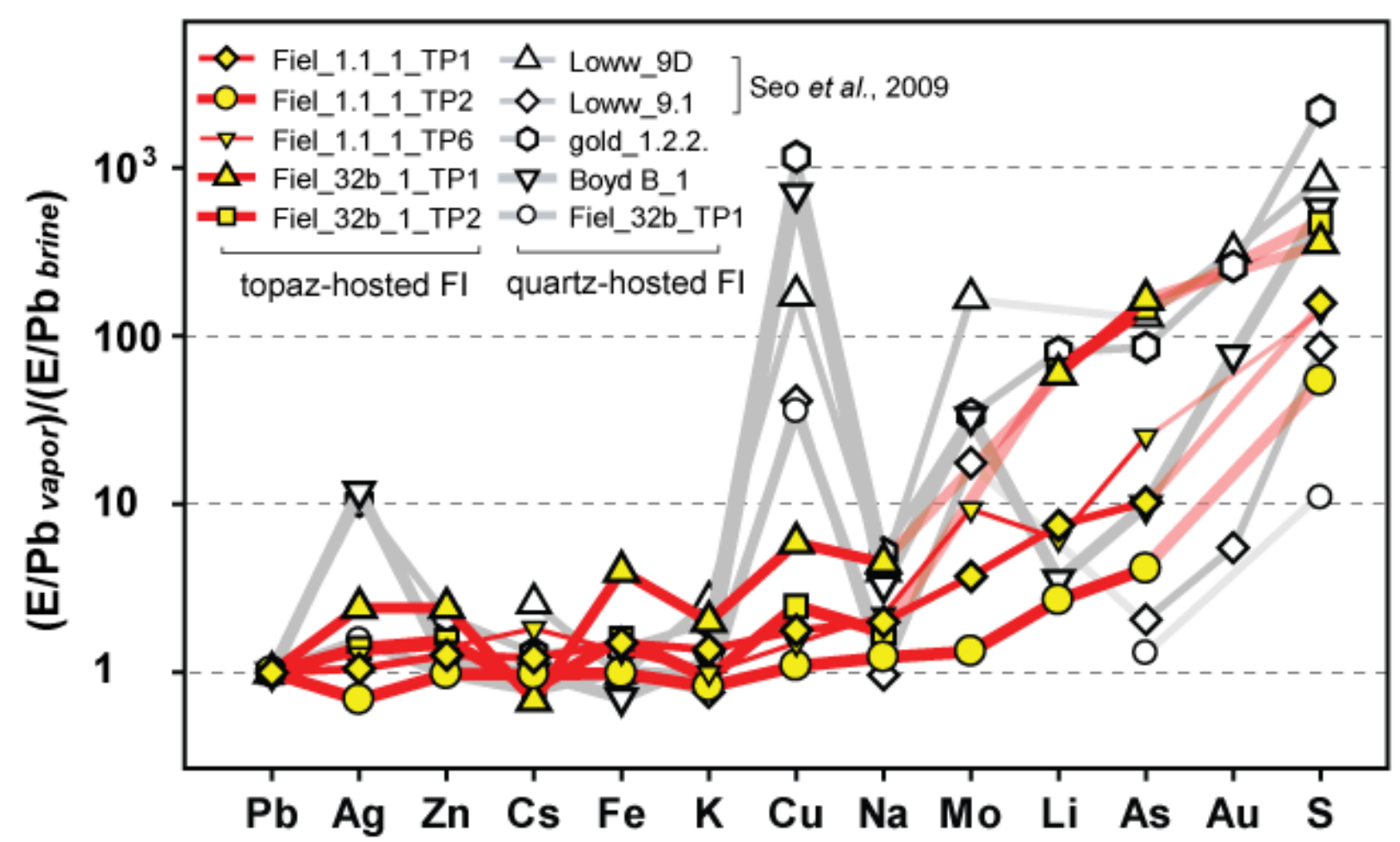

Figure 1. Partitioning of elements between cogenetic vapor and brine inclusion assemblages hosted in topaz (red and yellow) and quartz (gray and white) in several ore deposits associated with the Mole Granite (Australia) including quartzhosted boiling assemblages reported by Seo et al. (2009), first described by Audétat et al. (2000). Element concentrations are normalized to $\mathrm{Pb}$, which is most strongly enriched in the high-salinity brine and most analytically robust, and then plotted as ratios between vapor and brine to emphasize differences in relative enrichment. In quartz-hosted fluid inclusions, $\mathrm{Ag}, \mathrm{Cu}, \mathrm{As}, \mathrm{Au}$, and $\mathrm{S}$ are enriched in the vapor inclusions relative to $\mathrm{Pb}, \mathrm{Zn}, \mathrm{Cs}, \mathrm{Fe}, \mathrm{K}$ and $\mathrm{Na}$. Topaz-hosted fluids inclusions, however, show that $\mathrm{Cu}$ does not partition preferentially into the vapor, while $\mathrm{S}$ and As are strongly enriched in the coexisting vapor irrespective of host mineral.

\section{Post-entrapment $\mathrm{Cu}$ diffusion into quartz-hosted vapor inclusions}

To understand and assess post-entrapment modification in quartz-hosted vapor inclusions, we need to consider our new data from topaz and garnet in combination with the following published analytical and experimental observations:

(1) In hydrothermal experiments allowing separate sampling of coexisting saline liquid and vapor, $\mathrm{Cu}$ always fractionates in favor of the saline liquid (Pokrovski et al., 2005), but the addition of $\mathrm{H}_{2} \mathrm{~S}$ causes a 10 to 100 -fold enrichment of $\mathrm{Cu}$ in vapor relative to other chloride salts (Pokrovski etal., 2008).

(2) In contrast to these autoclave experiments, $\mathrm{Cu}$ concentrations in quartz-hosted vapor inclusions commonly exceed those in coeval brine inclusions, in many natural samples as well as synthetic-inclusion experiments with S-rich fluid systems (Nagaseki and Hayashi, 
Selective copper diffusion into quartz-hosted vapor inclusions: evidence from other host minerals, driving forces, and consequences for $\mathrm{Cu}$-Au ore formation

2008), but natural vapor inclusions in coeval topaz and garnet in this study do not show this enrichment.

(3) Copper enrichment in natural quartz-hosted vapor inclusions correlates with their sulfur content, with most assemblages showing a molar $\mathrm{Cu}: \mathrm{S}$ concentration greater or equal to $1: 2$. This ratio is consistent with the presence of a sizeable $\mathrm{CuFeS}_{2}$ crystal in such inclusions (Sawkins and Scherkenbach, 1981; Seo et al., 2009).

(4) Copper can be added at laboratory timescales by selective diffusion into natural vapor assemblages, and the extent of $\mathrm{Cu}$ introduction is enhanced by high initial sulfur and high acid concentrations in the vapor inclusions (Lerchbaumer and Audétat, 2012). Earlier experiments have shown that molecular $\mathrm{H}_{2}$ exchange between quartz-hosted fluid inclusions and external fluids occurs at laboratory time scales, allowing effective redox reequilibration of aqueous inclusions with the surrounding fluid (Mavrogenes and Bodnar, 1994; Hall and Sterner, 1995).

(5) Microanalytical data for gold indicate selective enrichment in some natural S-rich vapor inclusions hosted by quartz (Ulrich et al. 1999; Seo et al., 2009). In contrast to $\mathrm{Cu}$, preferential partitioning of $\mathrm{Au}$ into S-rich vapor has been confirmed experimentally, with $\mathrm{K}_{\mathrm{d}}$ $=\mathrm{Au}_{\mathrm{vapor}} / \mathrm{Au}_{\text {brine }}$ up to 7.5 at $450^{\circ} \mathrm{C}$ and 500 bar, provided that the vapor is acidic and contains $1 \mathrm{wt} \% \mathrm{H}_{2} \mathrm{~S}$ (Pokrovski et al., 2008).

Selective transport of $\mathrm{Cu}$ into and out of existing quartz-hosted fluid inclusions depends on two essential factors: an element- and mineral-specific diffusion mechanism, and a chemical driving force for $\mathrm{Cu}$ to exchange with an external reservoir, which we now discuss in turn.

\subsection{Charge-Balanced Ion Migration through Quartz}

Rapid diffusion of ions has long been known from experiments applying an electric potential difference between two aqueous electrolyte solutions separated by a quartz plate that is cut perpendicular to the c-axis of the crystal (Harris and Waring, 1937; Verhoogen, 1952). This electrolytic ion migration is highly directional and thought to occur through the staircase-like channels in the quartz structure. This channel between oxygen atoms has an approximate radius of $1 \AA$, through which $\mathrm{Li}^{+}$(effective ion radius $0.76 \AA$ ) and $\mathrm{Na}^{+}(1.02 \AA)$ can be rapidly transported at $300-500^{\circ} \mathrm{C}$, whereas $\mathrm{K}^{+}$transport is far slower (1.38 $\AA$; Harris and Waring, 1937). The former three elements, as well as $\mathrm{Cu}^{+}(0.77 \AA)$ and possibly $\mathrm{Ag}^{+}(1.15 \AA$; effective ion radii after Shannon, 1976) have been shown to be transported in and out of quartz-hosted fluid and melt inclusions using hydrothermal equilibration experiments (Li et al., 2009; Zajacz et al., 2009; Lerchbaumer and Audétat, 2012). Since the $\mathrm{Au}^{+}$ion (1.37 $\AA$ ) is much larger than these cations, $\mathrm{Au}$ is not expected to readily diffuse through quartz. No electrolytic diffusion experiments for $\mathrm{H}^{+}$have been reported to our knowledge, but exchange experiments by Zajacz et al. (2009) and Li et al. (2009) indicate that $\mathrm{H}^{+}$is at least as mobile in quartz as $\mathrm{Li}^{+}$and $\mathrm{Cu}^{+}$. Measurements of the typical time-decrease of direct-current conductivity through natural Na-Li-H-Al-bearing quartz (Kronenberg and Kirby, 1987) and self-diffusion experiments for oxygen in the presence of $\mathrm{H}_{2} \mathrm{O}$ (Elphick and Graham, 1988) 
Selective copper diffusion into quartz-hosted vapor inclusions: evidence from other host minerals, driving forces, and consequences for $\mathrm{Cu}$-Au ore formation

indicate that interstitial $\mathrm{H}^{+}$in quartz is partly coupled to $\mathrm{Al}^{3+}$ replacing $\mathrm{Si}^{4+}$ and thus rather immobile, whereas additional $\mathrm{H}^{+}$(supplied for example by an acidity gradients of the surrounding fluid) may contribute to much greater $\mathrm{H}^{+}$diffusivity in the direction of the c axis of quartz.

Post-entrapment diffusion of $\mathrm{Cu}$ into quartz-hosted vapor inclusions requires a complementary ion diffusion to maintain charge balance. To explain excess concentrations on the order $1 \mathrm{wt} \% \mathrm{Cu}$, as analyzed in many low-salinity porphyry-related vapor inclusions in which $\mathrm{Cu}$ is one of the major dissolved elements, requires balancing species of equal concentration. This confines possible exchange reactions to species within the major-component system $\mathrm{Na}-\mathrm{K}-\mathrm{Fe}-\mathrm{Cu}-\mathrm{Cl}-\mathrm{S}-\mathrm{O}-\mathrm{H}$, because no other element is present in a concentration that is high enough to charge-balance such major $\mathrm{Cu}$ addition. Given the experiments summarized above and our analytical data indicating that $\mathrm{M} / \mathrm{Na}$ ratios are not significantly host-mineral dependent, $\mathrm{H}^{+}$appear to be the most likely specie for outward diffusion to balance inward diffusion of $\mathrm{Cu}^{+}$(Lerchbaumer and Audétat, 2012).

\subsection{Driving Force for Cu Migration: $\mathrm{Cu}^{+} \mathrm{H}^{+}-1$ Exchange Dominated by Sulfur Geochemistry}

Inward diffusion of $\mathrm{Cu}$ into natural fluid inclusions trapped at high temperatures and pressures in ore veins seems paradoxical at first, considering that $\mathrm{Cu}$ concentration in the residual pore fluid surrounding the inclusion-hosting quartz is decreasing as a result of $\mathrm{Cu}$-Fe-sulfide precipitation upon fluid cooling and eventual dilution by invading meteoric water (Crerar and Barnes, 1976; Herzarkhani and Williams-Jones, 1998). In this section, we show that a gradient in chemical potential for $\mathrm{Cu}^{+} \mathrm{H}^{+}{ }_{-1}$ exchange is expected to be established as a result of overall cooling of natural fluid - rock systems, and that this gradient is capable of driving the observed quantities of $\mathrm{Cu}^{+}$from the surrounding rock-buffered fluid into S-rich vapor inclusions.

To quantify this effect, the thermodynamic dataset compiled in Heinrich (2005) was applied to a simple scenario for a quartz-hosted fluid inclusion cooling within a porphyry-Cu-Au ore environment. Our analytical data comparing garnet and topaz-hosted inclusions with earlier data from coeval quartz-hosted inclusions indicate that all major-element concentrations including $\mathrm{Na}, \mathrm{K}$ and $\mathrm{Fe}$ as well as $\mathrm{Cl}$-complexed trace elements such as $\mathrm{Pb}$ maintain their concentrations in coexisting high-salinity brines and low-salinity vapor inclusions. Although we cannot exclude some $\mathrm{Na}^{+}$diffusion out of the inclusion, we explore the limiting possibility that the inclusion system is open to only two types of major-element transfer: the ion exchange of $\mathrm{Cu}^{+} \mathrm{H}^{+}-1$ and the diffusion of elemental $\mathrm{H}_{2}$ between the fluid inclusion and the surrounding rock and its local pore fluid. Driving forces for the transfer of these two components in- or outward will be determined by multicomponent reactions in the system Na-K-Fe-Cu-Cl-S-O-H. The speciations of minor elements in the vapor inclusions, including $\mathrm{Au}$, are likely to be dominated by equilibria among the majorelement species.

Chemical equilibria inside the fluid inclusions include the following important reactions (and their combinations), which tend to proceed from left to right with decreasing temperature:

$$
2 \mathrm{H}_{2} \mathrm{O}+\mathrm{SO}_{2}=\mathrm{H}_{2} \mathrm{~S}+2 \mathrm{H}^{+}+\mathrm{SO}_{4}{ }^{2-} \quad \text { producing sulfuric acid }
$$


Selective copper diffusion into quartz-hosted vapor inclusions: evidence from other host minerals, driving forces, and consequences for $\mathrm{Cu}$-Au ore formation

$$
\begin{array}{ll}
\mathrm{SO}_{2}+3 \mathrm{H}_{2} 0=\mathrm{H}_{2} \mathrm{~S}+2 \mathrm{H}_{2} \mathrm{O} & \text { sulfur redox balance } \\
\mathrm{Cu}^{+}+\mathrm{Fe}^{2+}+2 \mathrm{H}_{2} \mathrm{~S}=\mathrm{CuFeS}_{2}+3 \mathrm{H}^{+}+1 / 2 \mathrm{H}_{2} 0 & \text { chalcopyrite precipitation }
\end{array}
$$

Chemical equilibria in the rock-buffered pore fluid outside the inclusions are subject to complex fluid-mineral buffering reactions, which we can express in simplified terms by:

$$
\begin{array}{ll}
\mathrm{K} \text {-feldspar }+\mathrm{H}^{+}=\text {muscovite }+ \text { quartz }+\mathrm{K}^{+} & \mathrm{pH} \text { buffer equilibrium } \\
{ }^{\prime} \mathrm{FeO} \mathrm{O}^{\prime}+\mathrm{H}_{2} \mathrm{O}=\text { magnetite }+\mathrm{H}_{2}{ }^{0} & \text { rock-dominated redox buffer }
\end{array}
$$

whereby 'FeO' stands for biotite and other ferrous silicates, in rocks that are typically affected by potassic alteration (K-feldspar, biotite, magnetite) with a partial overprint by phyllic alteration (muscovite, chlorite; using the empirical calibration for 'FeO' from Giggenbach, 1992; see table 4 in Heinrich, 2005). These $\mathrm{pH}$ - and redox-controlling equilibria in turn fix the concentrations of $\mathrm{Fe}, \mathrm{Cu}$, $\mathrm{Au}$ and $\mathrm{S}$ dissolved in the pore fluid in equilibrium with in the surrounding rock, if saturation with chalcopyrite, pyrite and gold is assumed (Heinrich, 2005). The rock system therefore acts as an unlimited reservoir or sink of the mobile components $\mathrm{Cu}^{+}, \mathrm{H}^{+}$and $\mathrm{H}_{2}$, whose activities are buffered by an excess of saturating minerals, i.e., albite $+\mathrm{K}$-feldspar + muscovite + quartz + 'FeO' + magnetite + pyrite + chalcopyrite or bornite + gold.

To predict the possible extent of chemical modification of a low-salinity vapor inclusion in this environment, we chose a starting composition based on high-temperature vapor inclusions from the Grasberg porphyry $\mathrm{Cu}-\mathrm{Au}$ deposit, where high gold as well as variably high copper concentrations were analyzed (Ulrich et al., 1999). In contrast to earlier papers inferring a high original $\mathrm{Cu}$ content from the average of all vapor analyses in a boiling assemblage $(1.2 \mathrm{wt} \% \mathrm{Cu}$ as analyzed by Ulrich et al., 1999), we here consider the possibility that the copper content may have initially been near the lower end of the analyzed range, i.e. $\sim 500 \mathrm{ppm}\left(0.008 \mathrm{~m} \mathrm{Cu}_{\text {tot }}\right)$, which is consistent with estimations based on experimental data in S-rich fluid systems (Zajacz et al., 2011). We assume that the inclusions trapped and maintained a high concentration of $\sim 2 \%$ total sulfur, assumed to be initially present in equal proportions of $\mathrm{SO}_{2}$ and $\mathrm{H}_{2} \mathrm{~S}(0.3 \mathrm{~m}$ each). This sulfur concentration is slightly higher than the maximum measured in the present study of garnet and topaz inclusions, but typical for low-salinity vapor inclusions in porphyry copper systems such as Bingham Canyon (Seo et al., 2009, 2012) and Bajo de la Alumbrera (Heinrich et al., 2011). Initial acid concentration $\left(\mathrm{H}^{+}+\mathrm{HCl}\right)$ was taken as $0.03 \mathrm{~m}(\mathrm{HCl}$ partitions into the vapor at high P-T; Palmer et al., 2004; Williams-Jones and Heinrich, 2005) but this value turns out to be of minor importance so long as it is lower than total $\mathrm{H}_{2} \mathrm{~S}$ and $\mathrm{SO}_{2}$ concentration.

In a series of free-energy minimization experiments we used the ETH-modified CSIROTHERMODATA package of Turnbull and Wadsley (1986) to compute the bulk composition and speciation inside this idealized fluid inclusion, assuming that $\mathrm{Cu}^{+}, \mathrm{H}^{+}$and $\mathrm{H}_{2}$ can freely exchange between the inclusion and the surrounding rock. Charge-balanced exchange of $\mathrm{Cu}^{+}$and $\mathrm{H}^{+}$between the inclusion interior and the surrounding rock-dominated environment is then described by the reaction 
Selective copper diffusion into quartz-hosted vapor inclusions: evidence from other host minerals, driving forces, and consequences for $\mathrm{Cu}$-Au ore formation

$$
\mathrm{Cu}^{+}{ }_{\text {inclusion }}+\mathrm{H}^{+}{ }_{\text {rock }}=\mathrm{Cu}^{+}{ }_{\text {rock }}+\mathrm{H}^{+}{ }_{\text {inclusion }}
$$

with

$$
\begin{aligned}
& \Delta \mathrm{G}_{\mathrm{r}}=-\mu_{\mathrm{Cu}+\text {,inclusion }}^{0}-\mathrm{RT} \ln \mathrm{a}_{\mathrm{Cu}+\text {,inclusion }}-\mu_{\mathrm{H}+\text {,rock }}^{0}-\mathrm{RT} \ln \mathrm{a}_{\mathrm{H}+\text {,rock }}+ \\
& +\mu_{\mathrm{Cu}+\text {,rock }}^{0}+\mathrm{RT} \ln \mathrm{a}_{\mathrm{Cu}+\text {,rock }}+\mu_{\mathrm{H}+\text {,inclusion }}^{0}+\mathrm{RT} \ln \mathrm{a}_{\mathrm{H}+\text {,inclusion }}
\end{aligned}
$$

The standard potentials $\mu^{0}$ in the inclusion and the surrounding rock are equal, if we assume thermal equilibrium and ignore pressure effects between the isochoric system forming a bubble in the inclusion, and the external environment that may not necessarily follow the boiling curve of the cooling fluid (the external fluid more likely cools at constant pressure and thereby evolves to a single-phase liquid; Heinrich et al., 2004). If the inclusion interior and the surrounding rock system attain a state of exchange equilibrium with regard to reaction (6), then $\Delta G_{r}=0$ and eq. (7) simplifies to

$$
\left(\mathrm{a}_{\mathrm{Cu}+} / \mathrm{a}_{\mathrm{H}+}\right)_{\text {rock }}=\left(\mathrm{a}_{\mathrm{Cu}+} / \mathrm{a}_{\mathrm{H}+}\right)_{\text {inclusion }}
$$

In the numerical equilibration experiments, redox potential was fixed at $\log \mathrm{f}_{02}=\mathrm{NNO}+2$, which constrains ан2 $_{2}$ outside as well as in the inclusion to the same value, close to the hematite + magnetite equilibrium at temperatures between 440 and $250{ }^{\circ} \mathrm{C}$. In a first step, a rock-buffered external system was equilibrated to calculate $\left(\mathrm{a}_{\mathrm{Cu}} / \mathrm{a}_{\mathrm{H}+}\right)_{\mathrm{rock}}$ at each temperature in steps of $10^{\circ}$, at a high ratio of minerals to fluid containing the same total chloride concentration as the inclusion. Speciation inside the fluid inclusion was subsequently computed iteratively for each temperature, varying the bulk composition by exchanging $\mathrm{Cu}^{+}$for $\mathrm{H}^{+}$until $\left(\mathrm{a}_{\mathrm{Cu}} / \mathrm{a}_{\mathrm{H}+}\right)_{\text {inclusion }}$ matched the activity ratio $\left(\mathrm{a}_{\mathrm{Cu}} / \mathrm{a}_{\mathrm{H}+}\right)_{\text {rock. }}$ Figure 2 compares the initial concentration of major components in the inclusion (= assumed trapping composition marked on the right-hand axis) with the resulting concentrations in the re-equilibrated inclusion at each temperature (heavy lines and symbols) and the corresponding concentrations in the rock-buffered pore fluid (thinner lines with equivalent symbols and colors). The total $\mathrm{Cu}$ content of the inclusion increases with decreasing equilibration temperature of the $\mathrm{Cu}^{+}-\mathrm{H}^{+}$exchange, because most of the inward-diffusing $\mathrm{Cu}$ precipitates as $\mathrm{Cu}-$ Fe-sulfide (heavy red line with round symbols). Bornite + pyrite are stable at re-equilibration temperatures above $360^{\circ} \mathrm{C}$, but increasing amounts of chalcopyrite are formed from 340 down to $250^{\circ} \mathrm{C}$. Even the dissolved copper concentration in the aqueous phase of the inclusion is higher than the assumed starting concentration, with a maximum near $350^{\circ} \mathrm{C}$, for the following reason. Although significant $\mathrm{H}^{+}$is removed in exchange for added $\mathrm{Cu}^{+}$to adjust charge balance (equilibrium 8), the total acid concentration $\left(\mathrm{H}^{+}+\mathrm{HCl}\right)$ in the inclusion fluid increases with decreasing reequilibration temperature, in contrast to its counterpart in the external rock-buffered pore fluid, which is progressively neutralized by feldspar hydrolysis (eq. 4). Acidity inside the inclusion is produced, beyond the initial $0.03 \mathrm{~m}$, by the precipitation of $\mathrm{Cu}$-Fe-sulfides (eq. 3), being ultimately derived from $\mathrm{H}_{2} \mathrm{~S}$. Due to the moderately high $\mathrm{H}_{2}$ fugacity imposed by the redox buffer in the rock, any initial $\mathrm{SO}_{2}$ becomes reduced to $\mathrm{H}_{2} \mathrm{~S}$ (eq. 2), contributing to $\mathrm{Cu}$-Fe-sulfide precipitation. More oxidized conditions would generate additional acidity inside the inclusions by the 
Selective copper diffusion into quartz-hosted vapor inclusions: evidence from other host minerals, driving forces, and consequences for $\mathrm{Cu}$-Au ore formation

disproportionation reaction (1), thus equally contributing to $\mathrm{H}^{+}$diffusion outward and $\mathrm{Cu}^{+}$diffusion inward. In real geological systems, some of the excess $\mathrm{H}^{+}$produced within the model inclusion will probably diffuse outward in exchange for some inward diffusion of $\mathrm{Na}^{+}$, but this will only contribute to further minimization of the total free energy of the system compared to the limiting case modeled here.

In summary, inward diffusion of $\mathrm{Cu}^{+}$indeed occurs against the gradient in $\mathrm{Cu}+$ activity and total dissolved copper concentration, driven by the even steeper outward gradient in $\mathrm{H}^{+}$activity. This acidity gradient in turn results from the cooling of acid sulfur species and the generation of $\mathrm{H}^{+}$ associated with internal precipitation of $\mathrm{Cu}-\mathrm{Fe}$-sulfide, caused by the large initial excess of $\mathrm{S}$ inside the fluid inclusion while the activities of all $\mathrm{S}$ species in the surrounding rock-buffered fluid decrease steeply with falling temperature. The magnitude of predicted $\mathrm{Cu}$ introduction therefore explains the microanalytical observations of $\mathrm{Cu} \sim 1 \mathrm{wt} \%$ at similar or somewhat higher $\mathrm{S}$ contents in many natural vapor inclusions (Fig. 2).

Gold has been modeled in the same equilibration calculations, as a trace-element whose solubility is determined by activities of $\mathrm{H}^{+}, \mathrm{H}_{2}$ and the two ligands $\mathrm{HS}^{-}$and $\mathrm{Cl}^{-}$(Stefansson and Seward, 2004). If our model fluid in the inclusion contained $10 \mathrm{ppm}$ as analyzed in the Grasberg vapor inclusions, gold is predicted to precipitate inside the inclusion upon cooling, but the activities of the solubilitydetermining bisulfide species inside the inclusion will be higher than those in the rock-buffered environment outside, where aqueous sulfide is consumed by sulfidation of Fe from rock-forming silicates (e.g., Sillitoe, 2010). This creates a driving force for Au to migrate out of the inclusion, but never to diffuse into a fluid inclusion after entrapment. We conclude, therefore, that high $\mathrm{Au}$ concentrations analyzed in porphyry-hosted vapor inclusions are likely to be correct or even minimum estimates for actual trapping concentrations. In contrast to the small $\mathrm{Cu}^{+}$ion, the large $\mathrm{Au}^{+}$ion $(1.37 \AA$ ) is also less likely to diffuse through the quartz structure, and therefore would be retained within the inclusion.

While species concentrations in this model are subject to uncertainties in thermodynamic data, the predicted direction of chemical driving forces shown in Figure 2 are robust, because they are dominated by mass balance in the $\mathrm{S}-\mathrm{O}-\mathrm{H}$ subsystem and do not depend critically on accurate representation of ore mineral solubility and aqueous $\mathrm{Cu}$ and $\mathrm{Au}$ speciation. They explain the extreme enrichment of $\mathrm{Cu}$ in S-rich vapor inclusions, by a mechanism that will affect coexisting brine inclusions to a smaller extent, because these are depleted in sulfur species $\left(\mathrm{H}_{2} \mathrm{~S}\right.$ and/or $\left.\mathrm{SO}_{2}\right)$. We cannot predict the post-entrapment behavior of brine inclusions for lack of thermodynamic data, but if their composition is dominated by chloride salts, any post-entrapment modification of element ratios should be detectable by microanalytical techniques. Studies by Hall and Sterner (1993) and Audétat and Günther (1999) suggest that post-entrapment loss of $\mathrm{H}_{2} \mathrm{O}$ from brine inclusions is more likely than modification of element ratios, with the notable exception of minor Li. If cooling ores are dominated by residual brines remaining in the pore space of the rock after removal of buoyant vapor, their excess concentration in base metals compared to their low $\mathrm{S}$ content may further assist diffusion of $\mathrm{Cu}$ into S-rich vapor inclusions. 
Selective copper diffusion into quartz-hosted vapor inclusions: evidence from other host minerals, driving forces, and consequences for $\mathrm{Cu}$-Au ore formation

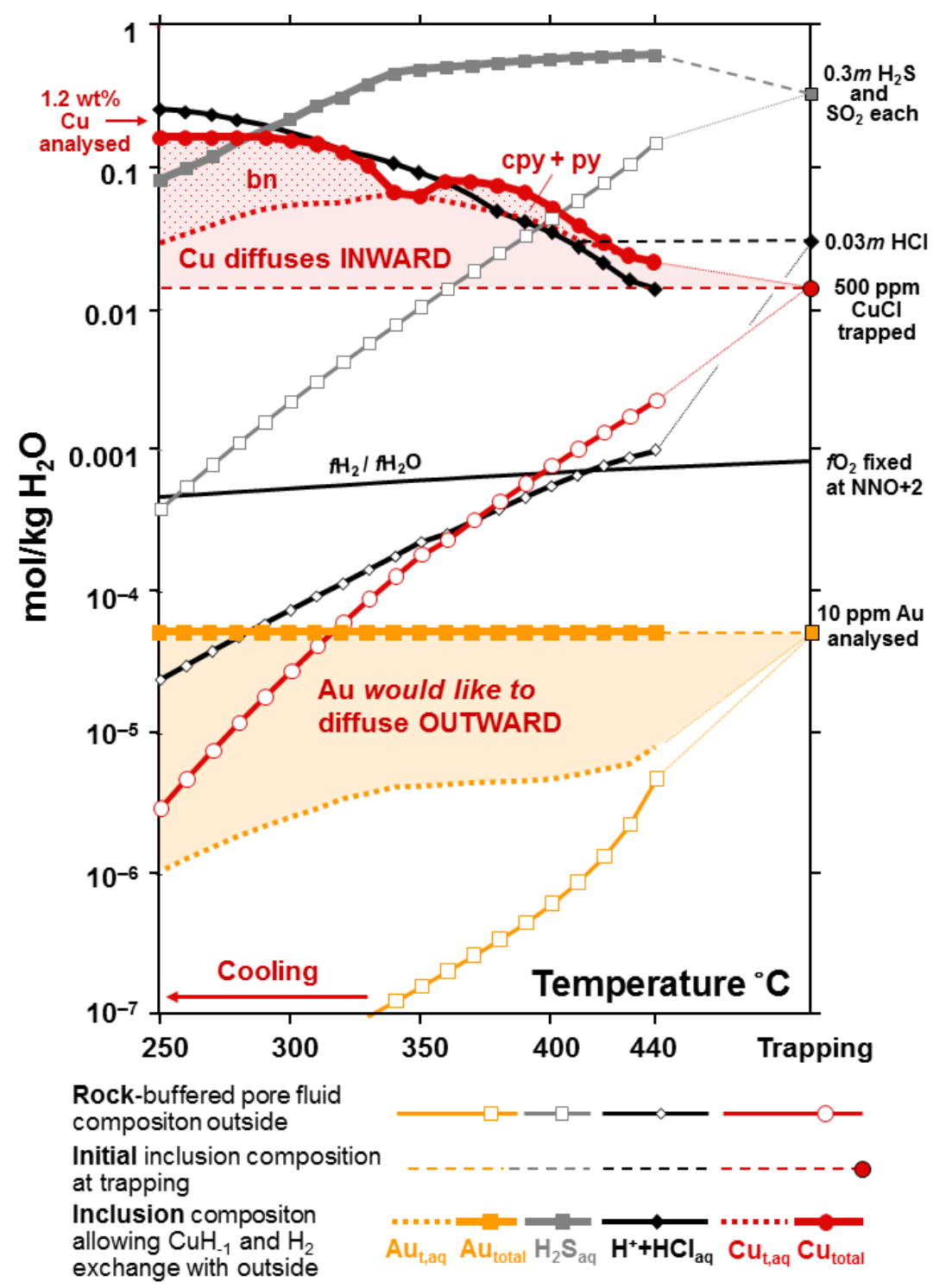

Figure 2. Multicomponent thermodynamic reaction model predicting the bulk composition and internal speciation of a quartz-hosted vapor inclusion that initially trapped a high concentration of sulfur but comparatively little Cu, like a typical high-temperature vapor fluid in a porphyry-Cu-Au deposit (compositional parameters except $\mathrm{Cu}$ similar to the Grasberg vapor analyzed by Ulrich et al., 1999, modeled with data for the Na-K-Fe-Cu-Cl-S-O-H system as in Heinrich, 2005). Allowing diffusive re-equilibration of $\mathrm{H}_{2}$ activity and charge-balanced exchange equilibrium of $\mathrm{Cu}^{+}$for $\mathrm{H}^{+}$with a rock-buffered fluid existing outside the host quartz can explain the extent of $\mathrm{Cu}$ enrichment observed in the Grasberg vapor inclusions after cooling. By contrast, Au has no driving force for inward transport, tentatively indicating that high $\mathrm{Au}$ concentrations analyzed in high-T vapor inclusions are unmodified trapping concentrations.

\section{Geological implications for Porphyry-style and Epithermal ore formation}

Total $\mathrm{Cu}$ concentrations in excess of $1 \mathrm{wt} \%$ in intermediate-density and vapor-like inclusions of low salinity, hosted by quartz veins in magmatic-hydrothermal systems, are likely to exceed the true trapping concentrations if a molar equivalent of sulfur or an excess of sulfur over copper is 
Selective copper diffusion into quartz-hosted vapor inclusions: evidence from other host minerals, driving forces, and consequences for $\mathrm{Cu}$-Au ore formation

present in the inclusion. Our earlier mass-balance estimates proposing that $\mathrm{Cu}$ introduced into a deposit as a single-phase fluid first partition into the vapor upon decompression, and then precipitates dominantly from the vapor phase (Landtwing et al., 2010; Seo et al., 2012) clearly needs to be revised (Lerchbaumer and Audétat, 2012). However, significant transport of $\mathrm{Cu}$ and particularly $\mathrm{Au}$ in S-rich vapor-like fluids remains an important natural process (Zajacz et al., 2010; Zajacz et al., 2011), compared to $\mathrm{Fe}, \mathrm{Zn}, \mathrm{Pb}$ that are invariably enriched in Cl-rich brines. The conclusion is still valid that porphyry-type deposits (especially $\mathrm{Cu}$-Au-rich systems formed at low pressure and shallow depths) are dominated by vapor in terms of fluid mass and volume (Henley and McNabb, 1978; Hedenquist et al., 1998), accompanied by condensation of a smaller amount of hypersaline brine (Williams-Jones and Heinrich, 2005; Landtwing et al., 2010; Sillitoe, 2010; Richards, 2011). In contrast to our earlier interpretations emphasizing the dominant role of vapor (Heinrich et al., 1999; Landtwing et al., 2010), copper is probably transported in comparable proportions by vapor and brine, after fluid phase separation at high temperature (Lerchbaumer and Audétat, 2012). Fluid inclusion distribution in zoned ore shells (Landtwing et al., 2012) and a recent hydrological model for the physical evolution of ascending magmatic fluids in porphyry systems (Weis et al., 2012) indicate that copper ore deposition occurs well above the region of phase separation, from two-phase fluids that together cool and expand across the boundary from the hot lithostatically-pressured fluid domain towards the hydrostatically-pressured environment, thus forming a confined copper ore shell.

Gold concentrations at ppm-levels in sulfur-rich vapor inclusions require additional confirmation, ideally by microanalytical data from diverse host minerals in addition to quartz. Based on the presently available evidence, preferential partitioning of $\mathrm{Au}$ into S-rich acidic vapor at nearmagmatic pressures and temperatures is not a geological artifact created by post-entrapment modification of fluid inclusions. If confirmed, this implies that the widespread separation of two fluid phases in the porphyry environment leads to chemical separation of $\mathrm{Au}$ from $\mathrm{Cu}$. This would enhance the possibility of selective transport of $\mathrm{Au}$ out of the porphyry environment into the surrounding, cooler and hydrostatically-pressured near-surface domain. There, the gold-rich vapor (and aqueous fluids derived by its cooling and contraction) will become powerful agents for gold mineralization in various types of epithermal ore deposits (e.g., Muntean et al.,2011).

Acknowledgements - We thank X. Yang for Dongguashan garnet samples and A. Audétat, T. Driesner and Z. Zajacz for discussions and reviews of this manuscript. Formal reviews By J. Hedenquist, Huayong Chen, and an anonymous referee further helped to clarify the paper. This work is supported by Swiss NSF Grant 200020-116693/1 and INHA UNIVERSITY Research Grant (INHA-46437). 
Selective copper diffusion into quartz-hosted vapor inclusions: evidence from other host minerals, driving forces, and consequences for $\mathrm{Cu}-\mathrm{Au}$ ore formation

\section{References}

Audétat, A., Günther, D., Heinrich, C.A., 1998. Formation of a magmatic-hydrothermal ore deposit: Insights with LA-ICP-MS analysis of fluid inclusions. Science 279, 2091-2094.

Audétat, A., Günther, D., 1999. Mobility and $\mathrm{H}_{2} \mathrm{O}$ loss from fluid inclusions in natural quartz crystals. Contributions to Mineralogy and Petrology 137, 1-14.

Audétat, A., Günther, D., Heinrich, C.A., 2000. Causes for large-scale metal zonation around mineralized plutons: Fluid inclusion LA-ICP-MS evidence from the Mole Granite, Australia. Economic Geology 95, 1563-1581.

Baker, T., Van Achterberg, E., Ryan, C.G., Lang, J.R., 2004. Composition and evolution of ore fluids in a magmatic-hydrothermal skarn deposit. Geology 32, 117-120.

Bodnar, R.J., Vityk, M.O., 1994. Interpretation of Microthermometric data for $\mathrm{H} 2 \mathrm{O}-\mathrm{NaCl}$ fluid inclusions, in: De Vivo, B., Frezzotti, M.L. (Eds.), Fluid inclusions in minerals: Methods and applications. Virginia Tech, Blacksburg, pp. 117-130.

Brady, J.B., Cherniak, D.J., 2010. Diffusion in Minerals An Overview of Published Experimental Diffusion Data, in: Zhang, Y.X., Cherniak, D.J. (Eds.), Diffusion in Minerals and Melts, pp. 899-920.

Cauzid, J., Philippot, P., Martinez-Criado, G., Menez, B., Laboure, S., 2007. Contrasting Cucomplexing behaviour in vapour and liquid fluid inclusions from the Yankee Lode tin deposit, Mole Granite, Australia. Chemical Geology 246, 39-54.

Cline, J.S., Bodnar, R.J., 1991. Can economic porphyry copper mineralization be generated by a typical calc-alkaline melt. Journal of Geophysical Research-Solid Earth and Planets 96, 8113-8126.

Cloke, P.L., Kesler, S.E., 1979. Halite trend in hydrothermal solutions. Economic Geology 74, 1823-1831.

Crerar, D.A., Barnes, H.L., 1976. Ore soulution chemistry 5. Soulubilities of chalcopyrite and chalcocite assemblages in hydrothermal soultion at 200 o to $350^{\circ} \mathrm{C}$. Economic Geology 71, 772-794.

Damman, A.H., Kars, S.M., Touret, J.L.R., Rieffe, E.C., Kramer, J., Vis, R.D., Pintea, I., 1996. PIXE and SEM analyses of fluid inclusions in quartz crystals from the K-alteration zone of the Rosia Poieni porphyry-Cu deposit, Apuseni mountains, Rumania. European Journal of Mineralogy 8, 10811096.

Eadington, P.J., 1983. A fluid inclusion investigation of ore formation in a tin-mineralized granite, New England, New South Wales. Economic Geology 78, 1204-1221.

Eastoe, C.J., 1982. Physics and chemistry of the hydrothermal system at the Panguna porphyry copper deposit, Bougainville, Papua New Guinea. Economic Geology 77, 127-153. 
Selective copper diffusion into quartz-hosted vapor inclusions: evidence from other host minerals, driving forces, and consequences for $\mathrm{Cu}$-Au ore formation

Elphick, S.C., Graham, C.M., 1988. The effect of hydrogen on oxygen diffusion in quartz Evidence for fast proton transients. Nature 335, 243-245.

Frank, M.R., Simon, A.C., Pettke, T., Candela, P.A., Piccoli, P.M., 2011. Gold and copper partitioning in magmatic-hydrothermal systems at $800^{\circ} \mathrm{C}$ and $100 \mathrm{MPa}$. Geochimica et Cosmochimica Acta 75, 2470-2482.

Günther, D., Audétat, A., Frischknecht, R., Heinrich, C.A., 1998. Quantitative analysis of major, minor and trace elements in fluid inclusions using laser ablation inductively coupled plasma mass spectrometry. Journal of Analytical Atomic Spectrometry 13, 263-270.

Giggenbach, W.F., 1992. SEG distinguished lecture - Magma degassing and mineral deposition in hydrothermal system along convergent plate boundaries. Economic Geology 87, 1927-1944.

Guillong, M., Heinrich, C.A., 2007. Sensitivity enhancement in laser ablation ICP-MS using small amounts of hydrogen in the carrier gas. Journal of Analytical Atomic Spectrometry 22, 14881494.

Guillong, M., Meier, D.L., Allan, M.M., Heinrich, C.A., Yardley, B.W.D., 2008. SILLS: A MATLABbased program for the reduction of laser ablation ICP-MS data of homogeneous materials and inclusions. Mineralogical Association of Canada Short Course 40, 328-333.

Hall, D.L., Sterner, S.M., 1993. Preferential water-loss from synthetic fluid inclusions. Contributions to Mineralogy and Petrology 114, 489-500.

Hall, D.L., Sterner, S.M., 1995. Experimental diffusion of hydrogen into synthetic fluid inclusions in quartz. Journal of Metamorphic Geology 13, 345-355.

Harris, P.M., Waring, C.E., 1937. Diffusion of lithium ions through quartz in an electric field. Journal of Physical Chemistry 41, 1077-1085.

Hedenquist, J.W., Arribas, A., Reynolds, T.J., 1998. Evolution of an intrusion-centered hydrothermal system: Far Southeast-Lepanto porphyry and epithermal $\mathrm{Cu}$-Au deposits, Philippines. Economic Geology 93, 373-404.

Heinrich, C.A., Ryan, C.G., Mernagh, T.P., Eadington, P.J., 1992. Segregation of ore metals between magmatic brine and vapor - A fluid inclusion study using PIXE microanalysis. Economic Geology 87, 1566-1583.

Heinrich, C.A., Günther, D., Audétat, A., Ulrich, T., Frischknecht, R., 1999. Metal fractionation between magmatic brine and vapor, determined by microanalysis of fluid inclusions. Geology 27, 755-758.

Heinrich, C.A., Pettke, T., Halter, W.E., Aigner-Torres, M., Audetat, A., Gunther, D., Hattendorf, B., Bleiner, D., Guillong, M., Horn, I., 2003. Quantitative multi-element analysis of minerals, fluid and 
Selective copper diffusion into quartz-hosted vapor inclusions: evidence from other host minerals, driving forces, and consequences for $\mathrm{Cu}$-Au ore formation

melt inclusions by laser-ablation inductively-coupled-plasma mass-spectrometry. Geochimica et Cosmochimica Acta 67, 3473-3497.

Heinrich, C.A., 2005. The physical and chemical evolution of low-salinity magmatic fluids at the porphyry to epithermal transition: a thermodynamic study. Mineralium Deposita 39, 864-889.

Heinrich, C.A., Erni, M., Von Quadt, A., Márquez - Zavlía, F., 2011. Life-times and scales of CuAu-mineralizing magmatic-hydrothermal processes: Farallón Negro (Argentina), Proceedings of the 11th Biennial SGA Meeting: Let's Talk Ore Deposits. Society for Geology Applied to Mineral Deposits, Antofagasta, Chile.

Henley, R.W., McNabb, A., 1978. Magmatic vapor plumes and groundwater interation in porphyry copper emplacement. Economic Geology 73, 1-20.

Herzarkhani, A., Williams-Jones, A.E., 1998. Controls of alteration and mineralization in the Sungun porphyry copper deposit, Iran: Evidence from fluid inclusions and stable isotopes. Economic Geology 93, 651-670.

Ingrin, J., Blanchard, M., 2006. Diffusion of hydrogen in minerals. Water in Nominally Anhydrous Minerals 62, 291-320.

Kamenetsky, V.S., Danyushevsky, L.V., 2005. Metals in quartz-hosted melt inclusions: Natural facts and experimental artifacts. American Mineralogist 90, 1674-1678.

Krauskopf, K.B., 1964. The possible role of volatile metal compounds in ore genesis. Economic Geology 59, 22-45.

Kronenberg, A.K., Kirby, S.H., 1987. Ionic-conductivity of quartz - DC time - dependence and transition in charge-carriers. American Mineralogist 72, 739-747.

Landtwing, M.R., Furrer, C., Redmond, P.B., Pettke, T., Guillong, M., Heinrich, C.A., 2010. The Bingham Canyon Porphyry Cu-Mo-Au Deposit. III.Zoned Copper-Gold Ore Deposition by Magmatic Vapor Expansion. Economic Geology 105, 91-118.

Lerchbaumer, L., Audétat, A., 2012. High Cu concentrations in vapor-type fluid inclusions: An artifact? Geochimica et Cosmochimica Acta 88, 255-274.

Li, Y., Audétat, A., Lerchbaumer, L., Xiong, X.L., 2009. Rapid Na, Cu exchange between synthetic fluid inclusions and external aqueous solutions: evidence from LA-ICP-MS analysis. Geofluids 9, 321-329.

Mavrogenes, J.A., Bodnar, R.J., 1994. Hydrogen movement into and out of fluid inclusions in quartz - ExperImental evidence and geological implications. Geochimica et Cosmochimica Acta 58, 141-148. 
Selective copper diffusion into quartz-hosted vapor inclusions: evidence from other host minerals, driving forces, and consequences for $\mathrm{Cu}$-Au ore formation

Muntean, J.L., Cline, J.S., Simon, A.C., Longo, A.A., 2011. Magmatic-hydrothermal origin of Nevada's Carlin-type gold deposits. Nature Geoscience 4, 122-127.

Nagaseki, H., Hayashi, K.I., 2008. Experimental study of the behavior of copper and zinc in a boiling hydrothermal system. Geology 36, 27-30.

Palmer, D.A., Simonson, J.M., Jensen, J.P., 2004. Partitioning of electrolytes to steam and their solubilities in steam., in: Palmer, D.A., Fernandez-Prini, R., Harvey, A.H. (Eds.), Aqueous Systems at Elevated Temperatures and Pressures: Physical Chemistry in Water, Steam and Hydrothermal Solutions. Elsevier, pp. 407-439.

Pokrovski, G.S., Roux, J., Harrichoury, J.C., 2005. Fluid density control on vapor-liquid partitioning of metals in hydrothermal systems. Geology 33, 657-660.

Pokrovski, G.S., Borisova, A.Y., Harrichoury, J.C., 2008. The effect of sulfur on vapor-liquid fractionation of metals in hydrothermal systems. Earth and Planetary Science Letters 266, 345-362.

Richards, J.P., 2011. Magmatic to hydrothermal metal fluxes in convergent and collided margins. Ore Geology Reviews 40, 1-26.

Roedder, E., 1984. Fluid inclusions. Reviews in Mineralogy 12, 1-\&.

Ryan, C.G., Heinrich, C.A., Mernagh, T.P., 1993. PIXE microanalysis of fluid inclusions and its application to study ore metal segregation between magmatic brine and vapor. Nuclear Instruments \& Methods in Physics Research Section B-Beam Interactions with Materials and Atoms 77, 463-471.

Sawkins, F.J., Scherkenbach, D.A., 1981. High copper content of fluid inclusions in quartz from Northern Sonora - Implications for ore-genesis theory. Geology 9, 37-40.

Seo, J.H., Guillong, M., Heinrich, C.A., 2009. The role of sulfur in the formation of magmatichydrothermal copper-gold deposits. Earth and Planetary Science Letters 282, 323-328.

Seo, J.H., Guillong, M., Aerts, M., Zajacz, Z., Heinrich, C.A., 2011. Microanaly sis of S, Cl, and Br in fluid inclusions by LA-ICP-MS. Chemical Geology 284, 35-44.

Seo, J.H., Guillong, M., Heinrich, C.A., 2012. Separation of Molybdenum and Copper in Porphyry Deposits: The Roles of Sulfur, Redox and pH in Ore Mineral Deposition at Bingham Canyon. Economic Geology 107, 333-356.

Seward, T.M., 1984. The formation of lead (II) chloride complexes to $300{ }^{\circ} \mathrm{C}-\mathrm{A}$ spectrophotometric study. Geochimica et Cosmochimica Acta 48, 121-134.

Shannon, R.D., 1976. Revised effective ionic-radii and systematic studies of interatomic distances in halides and chalcogenides. Acta Crystallographica Section A 32, 751-767. 
Selective copper diffusion into quartz-hosted vapor inclusions: evidence from other host minerals, driving forces, and consequences for $\mathrm{Cu}$-Au ore formation

Sillitoe, R.H., 2010. Porphyry Copper Systems. Economic Geology 105, 3-41.

Simon, A.C., Pettke, T., Candela, P.A., Piccolli, P.M., Heinrich, C.A., 2006. Copper partitioning in a melt-vapor-brine-magnetite-pyrrhotite assemblage. Geochimica et Cosmochimica Acta 70, 55835600 .

Stefansson, A., Seward, T.M., 2004. Gold(I) complexing in aqueous sulphide solutions to 500 degrees $C$ at 500 bar. Geochimica et Cosmochimica Acta 68, 4121-4143.

Turnbull, A.G., Wadsley, M.W., 1986. The CSIRO-SGTE THERMODATA System (Version V). Commonwealth Scientific and Industrial Research Organisation, Port Melbourne, Division of Mineral Chemistry Communications.

Ulrich, T., Gunther, D., Heinrich, C.A., 1999. Gold concentrations of magmatic brines and the metal budget of porphyry copper deposits. Nature 399, 676-679.

Verhoogen, J., 1952. Ionic diffusion and electrical conductivity in quartz. American Mineralogist 37, 637-655.

Weis, P., Driesner, T., Heinrich, C.A., 2012. Porphyry-Copper Ore Shells Form at Stable Pressure-Temperature Fronts Within Dynamic Fluid Plumes. Science.

Williams-Jones, A.E., Heinrich, C.A., 2005. 100th Anniversary special paper: Vapor transport of metals and the formation of magmatic-hydrothermal ore deposits. Economic Geology 100, 12871312.

Yang, X., Xu, Z., Seo, J.H., Lu, X., Guillong, M., 2009. Fluid properties in porphyry-style to skarnhosted copper mineralization at Dongguashan, SE China. Geochimica et Cosmochimica Acta 73, A1480-A1480.

Zajacz, Z., Hanley, J.J., Heinrich, C.A., Halter, W.E., Guillong, M., 2009. Diffusive reequilibration of quartz-hosted silicate melt and fluid inclusions: Are all metal concentrations unmodified? Geochimica et Cosmochimica Acta 73, 3013-3027.

Zajacz, Z., Seo, J.H., Candela, P.A., Piccoli, P.M., Heinrich, C.A., Guillong, M., 2010. Alkali metals control the release of gold from volatile-rich magmas. Earth and Planetary Science Letters 297, 5056.

Zajacz, Z., Seo, J.H., Candela, P.A., Piccoli, P.M., Tossell, J.A., 2011. The solubility of copper in high-temperature magmatic vapors: A quest for the significance of various chloride and sulfide complexes. Geochimica et Cosmochimica Acta 75, 2811-2827. 